Article

\title{
Environmental Education Catalyzed by Tourism: Ecoliteracy Initiatives on the Coast of Kenya
}

\author{
Nina Berman
}

Citation: Berman, N. Environmental Education Catalyzed by Tourism: Ecoliteracy Initiatives on the Coast of Kenya. Sustainability 2021, 13, 8501. https://doi.org/10.3390/su13158501

Academic Editors: Lóránt Dénes Dávid, Peter Szende and Martin Balázs Zsarnóczky

Received: 19 June 2021

Accepted: 13 July 2021

Published: 29 July 2021

Publisher's Note: MDPI stays neutral with regard to jurisdictional claims in published maps and institutional affiliations.

Copyright: (C) 2021 by the author. Licensee MDPI, Basel, Switzerland. This article is an open access article distributed under the terms and conditions of the Creative Commons Attribution (CC BY) license (https:// creativecommons.org/licenses/by/ $4.0 /)$.
School of International Letters and Cultures, Arizona State University, Phoenix, AZ 85287-1202, USA;

Nina.Berman@asu.edu

\begin{abstract}
The Diani-Ukunda area on the Kenyan coast is one of the main tourism centers of the country. Over time, individuals who originally visited the area as tourists have started sustainability initiatives that are in part funded through donor networks from abroad (drawing on individuals who visited the country initially as tourists). This essay explores select German initiatives in the educational sector that have emerged in the context of the area's tourism industry. Diani Maendeleo Academy (a secondary school for girls) and the six primary and secondary schools known as Mekaela Academies collectively serve a significant portion of the population of the larger Diani-Ukunda area, including the hinterland extending widely into Kwale County. The study was designed to assess the schools' approach toward sustainability and ecoliteracy, and centered on the following questions: 1. What kinds of sustainable practices are promoted in the select schools? 2. In what ways do students who attend these schools display environmental literacy? 3. Do these initiatives address UN SDGs, known as Education for Sustainable Development (ESD)? The study follows an interdisciplinary mixed method approach and is based on interviews, survey instruments, research on ecoliteracy and educational policy, and fieldwork data from previous stays. Findings reveal a lesser-known dimension of tourism: namely, the successful pursuit of ESD in schools thriving in the context of tourism through an integrated approach towards teaching ecoliteracy.
\end{abstract}

Keywords: sustainable tourism; humanitarianism; ecoliteracy; education for sustainable development; sustainability; sustainable development goals; citizen aid; Kenya; Kwale County; Germany

\section{Introduction}

In Earth in Mind: On Education, Environment, and the Human Prospect, environmentalist and educator David W. Orr laments the fact that educational frameworks are not designed to address the urgent need for raising awareness about impending global ecological disasters: "For the most part, however, we are still educating the young as if there were no planetary emergency" [1] (p 27). The concern Orr articulates in his 1994 publication should have, by now, amplified into outrage and translated into action. Unfortunately, however, what Orr wrote almost three decades ago is still true for many educational institutions around the world. While we have known about The Limits to Growth since 1972, not enough of the insights presented by scientists over the past 50 years have been included in the curricula of schools and universities, nor have they reached the awareness of the larger public. The narratives and power structures that enable neoliberal growth, wealth disparity, and environmental destruction have overruled the insights of scientists whose evidence has triggered only low-level mitigation.

Given the persisting lack of ecological awareness and action in the face of the alarming state of the planet, tourism has, for decades, emerged as a main culprit for negatively affecting the natural and social environment. By some recent calculations, tourism is responsible for $8 \%$ of carbon emissions [2] (p. 522). The sector also has been chastised for causing environmental degradation [3] and for escalating economic precarity and social inequality [4]. However, since the 1980s, the sector has responded to the often scathing 
critiques by creating sustainable tourism alternatives; in fact, the terms "ecotour" and "ecotourism" emerged in the 1970s and early 1980s, though initially they referred more to consciousness raising about wildlife and natural habitats than to traveling in sustainable ways [5]. Sustainable tourism continues to grow its share of the overall multi-trillion-dollar tourism market, and was "estimated at 181.1 billion U.S. dollars in 2019" [6]. While the industry has generated viable models and best practices of sustainable tourism [7-12], recent studies also address the negative impact of some ecotourism projects on the environment, as related to biodiversity [13], forests [14] and bird populations [15], to mention a few examples. The challenge of how to make tourism sustainable persists, in particular with regard to the larger socio-ecological systems in which particular tourism industries exist. Some models are pursuing a holistic approach by expanding the educational aspects of sustainable tourism programs to include the larger community [16]. Community-based sustainable tourism is another relevant model in this regard.

Kenya is known for its substantial ecotourism programs and conservation approaches [17-22], including the establishment of programs that train Kenyan citizens to take on roles in conservation [23,24]. The extensive public discourse on wildlife conservancy and the environment is also having an impact on the Kenyan educational system. Some research exists on the views held about conservation by Kenyan school children [25] and teachers [26], and on the implementation of ESD in the school system [27,28]. Not yet studied, however, are educational sustainability initiatives within the Kenyan school system that began with and are sustained by tourism and that have a significant impact on local infrastructures. One such example includes educational initiatives that are located in the Diani-Ukunda area, one of the main tourism areas in Kenya. Many private primary and secondary schools were founded by individuals who first came to the area as tourists and are also supported to a large degree by sponsors who first learned about these initiatives as tourists [29] (pp. 89-101). Some of these schools have a pronounced emphasis on environmental education and aim to increase the ecological literacy of their students. Given their intrinsic connection to the tourism industry, the initiatives thus speak to Wil Munsters's argument regarding the potentially synergistic drive of sustainable tourism (2008), in this case, a spin-off of tourism that supports local sustainability education [30].

The term ecological literacy, or ecoliteracy, is generally attributed to Orr and physicist Fritjof Capra, who advocated already in the late 1990s for the importance of educating students of all ages about the connection between human behavior and the environment (though there have been other studies on the subject [31-34]). Capra also co-founded the Center for Ecoliteracy in Berkeley in 1995. The nonprofit has published a large number of essential visions for ecological education [35]. Ecoliteracy, neutrally speaking, denotes the awareness of and factual knowledge about the ecological state of the planet. Initiatives to increase ecoliteracy propose that a high level of ecoliteracy among the population is needed in order for humans to recreate ecological stability on the planet and to ensure that the planet remains habitable for humans and other species. As such, the concept is one of the key terms in the broader field of environmental and ecological education, a topic that is pursued by a wide range of governmental and non-governmental stakeholders. Today, ecoliteracy is also connected to the global push for "education for sustainable development." Based on the 17 categories for sustainable development that were agreed upon by the United Nations member states in 2015 [36], "education for sustainable development" is the umbrella term that has become a category for ranking institutions across the planet, as can be seen in the impact rankings published by the Times Higher Education [37].

This essay explores the approach toward teaching sustainability and ecoliteracy in select private schools in the Diani-Ukunda area on the coast south of Mombasa, an area economically deeply connected to international and, increasingly, domestic tourism. Diani Maendeleo Academy (a secondary school for girls) and the six primary and secondary schools known as Mekaela Academies collectively serve a significant portion of the population of the larger Diani-Ukunda area, including the hinterland extending widely into Kwale County [38]. These schools are predominately run by Germans and other Euro- 
peans, who initially came to the area as tourists. They are also sponsored substantially by a donor network that consists of many individuals who first encountered the projects while they were visiting the area as tourists. Specifically, this essay discusses the ways in which ecological literacy is integrated into the schools' broader approach to sustainability, such as the schools' infrastructure, ecological practices on the schools' compounds and extracurricular activities, and how this approach is reflected in the ecological consciousness of students.

\section{Methods}

Research for this study centered on the following questions:

- What kinds of sustainable practices are promoted in the select schools, both of which emerged in the context of tourism and are supported to a large extent by tourists, former and present?

- In what ways do students who attend these select schools display environmental literacy?

- In what ways do these initiatives address UN Sustainable Development Goals, as part of what is known as Education for Sustainable Development (ESD)?

Multiple methodologies were employed to gather information and ground it in its complex sociocultural context [39]. The study draws substantially on ethnographic fieldwork. I have been visiting the area since 1980 and pursued my first research project in Diani in 1998. My initial encounter with the schools discussed here goes back to fieldwork for a project on tourism in Diani that was conducted over several stays between November 2009 and June 2016. Back then, I used participant observation, survey instruments, qualitative interviews, geographical information systems (GIS) tools and archival research for data collection. My long-term familiarity with the area has given me insight into change over time and allowed me to build crucial relationships with individuals, including directors of the schools under discussion here, who were willing to share their views with me.

The study on ecoliteracy presented here was inspired by this research, in particular the realization that environmental initiatives were part and parcel of many schools in Diani-Ukunda, especially those founded and/or run and supported by Germans and other Europeans who had first come to the area as tourists. For most of the time, I was conducting research specific to ecoliteracy, Kenyan schools were closed, as Kenya implemented a rigorous lockdown of the country from March 2020 to January 2021 in response to the COVID-19 pandemic (only Form 4 students returned in October). As I was unable to travel to Kenya in person, I conducted interviews through various digital channels and with the help of local contacts. Between July 2020 and July 2021, I interviewed personnel from Diani Maendeleo Academy and Mekaela Academies, including directors and teachers, and gathered information about current ecoliteracy initiatives at the schools via Skype, WhatsApp and email and on location in June/July 2021. The interviews were held in English, German, and Kiswahili. Additional data collection occurred via digital means: questionnaires were sent to students at the two institutions, with a total of 94 returned. Finally, I consulted scholarship on sustainability in German and Kenyan school curricula and scholarship on environmental education and climate change activism guided the analysis. Overall, the study is thus based on an interdisciplinary mixed method approach [40].

The presentation of results is preceded by a review of the educational policy framework in Germany and Kenya and an overview of the tourism landscape that is the immediate contexts for the schools presented here. The results section consists of an introduction to Mekaela Academies and Diani Maendeleo Academy, followed by a discussion of their environmental initiatives and the results from the survey instruments.

\section{Background: German and Kenyan Environmental and Educational Policy Frameworks}

In order to better understand why so many Germans in Kenya are involved in sustainability education, a review of the German educational policy framework was conducted, assuming that it might have provided blueprint models for the Kenyan schools that were run 
and supported primarily by Germans. Germany has a long tradition of ecological activism, legislation, and practice, and the ecoliteracy of the general population is comparatively high, making it, as some suggest, "the greenest nation" [41-43]. As Mandy Singer-Brodowski et al. summarize regarding Education for Sustainable Development (ESD) [44]:

Germany had already successfully advanced ESD in the context of the UN Decade ESD (Dannenberg and Grapentin 2016). The German National Committee framed the slogan "from project to structure" (2013) to intensify further efforts. The German Ministry of Education and Research (BMBF) has followed UNESCO's call for the implementation of GAP on ESD in all national education systems and launched an extensive process. A National Platform was set up which brings together high-level representatives of politics, academia, industry, and society. Additionally, six expert forums consult the National Platform and developed a National Action Plan for early childhood education, school, vocational education and training, higher education, informal and non-formal learning/youth and local authorities [45] (p. 494).

(See also the websites of the federal Bundesministerium für Umwelt, Naturschutz und nukleare Sicherheit and the German UNESCO-commission and the Ministry for Education and Research, which provide guidelines and materials for integrating ecological topics into the various curricula $[46,47]$.)

Given this elaborate institutional grounding of ESD in Germany, one would expect that the teaching of ecological knowledge and consciousness was central to the German education system, but a comparison of various core curricula shows that ecology is not anchored in the curriculum in ways that reflect German public discourse, legislation, and activism. In Germany's federal system, educational frameworks are defined by the individual states, and a review of select samples reveals that ecology is not integrated centrally (see, for example, the curriculum as defined in the state of Hesse [48] and the city of Berlin [49]). Several studies elaborate on the issue. Singer-Brodowski et al. explore the degree to which ESD has been incorporated into early childhood education, school education, and higher education in Germany. They conclude that, overall, "ESD has been taken up. It demonstrates, however that ESD-implementation still has a far way to go if the aim is an integration of ESD as an important cross-sectional topic in educational contexts" [45] (p. 503). While early childhood education showed the highest degree of implementation, in higher education, the authors find, "ESD as an educational concept seems rare" [45] (p. 503). (Jörg Nilgens [50] and Ulas Incedal [51] have completed additional studies of environmental education in the German school system.)

Inka Bormann and Jutta Nikel's analysis of dimensions of implementation of ESD in various sectors of the communal-level educational sector in Germany also illuminated the challenges surrounding ESD policy implementation. The authors conclude that, even though the "the programme of the UN decade is a world-wide 'push factor' for processes of policy implementation at different levels," a gap exists between policy documents and policy implementation that can be tied to a specific governance regime and related to the openness of normative concepts, among other factors" [52]. Similarly, Sandra Sprenger and Birte Nienaber document the differing levels of ESD implementation in Geography programs across higher education [53]. Nina Kolleck, who conducted a largescale study in Germany based on social network theory, also confirms that actors tied to the formal educational system are less influential than NGOs and governmental actors in implanting ESD: "Schools occupy significantly less central, prestigious and influential network positions than representatives of government or NGOs. In fact, it was strikingly clear that schools still take the back seat in the process of implementing ESD" [54] (p. 324). The link between scientists and policymakers and the impact of organization culture have been acknowledged as crucial factors in implementing ESD policies [55,56].

Overall, these analyses show that the educational system may in fact lag behind the ecoliteracy of the larger population. The high level of environmental consciousness can be seen in the 2019-2020 participation of students in Fridays for Future, German legislation, and the country's established recycling practices, all of which has roots in a substantial 
200-year history. From Romanticism and the teachings of Sebastian Kneipp to the activities of the Wandervogel movement, the founding of the Green Party, and recent legislation, Germany's environmental culture evolved over a long period of time, which explains its scope and scale. However, implementation of ESD in the educational system, including in higher education across the planet [57], is still in the early stages.

The German commitment to ecologization is matched in Kenya by a strong legal and policy framework designed to lead Kenya toward a sustainable future. Kenyan society is facing environmental challenges on a large scale, from water and electricity shortages to soil erosion and desertification. These predicaments have been amplified by the severe repercussions of climate change and exponential population growth. In order to address these profound challenges, Kenya is pursuing ambitious projects, such as the geothermal plants in the Rift Valley (though they have had a negative impact on the population of the region [58]), and also has a broad activist base, such as the large-scale Green Belt Movement that is dedicated to fighting soil erosion by planting trees (51 million since 1977) [59]. From Hydroponics Africa [60] and Kings Biofuels [61] to Twiga Foods [62] and Wheeling Fruits [63], Kenyan entrepreneurs are at the forefront of designing local solutions to Kenya's problems $[64,65]$. The celebration of Kenyan entrepreneurs, it should be noted, is highly gendered, a dimension not unfamiliar in societies across the planet [66].

Kenyan legislation addresses the increasing necessity of regulating development and, in particular, increasing environmental pressure. Several laws stand out:

- The Environmental Management and Coordination Act (1999). This law was "an Act of Parliament to provide for the establishment of an appropriate legal and institutional framework for the management of the environment and for the matters connected therewith" [67], It "is the framework law on environmental management and conservation. EMCA establishes among others the following institutions; National Environment Management Authority, Public Complaints Committee, National Environment Tribunal, National Environment Action Plan Committees, and County Environment Committees. The National Environment Management Authority (NEMA) was established as the principal instrument of government charged with the implementation of all policies relating to the environment, and to exercise general supervision and coordination over all matters relating to the environment. In consultation with the lead agencies, NEMA is empowered to develop regulations, prescribe measures and standards and, issue guidelines for the management and conservation of natural resources and the environment" [68].

- The Constitution of Kenya (2010), which in Article 10 makes sustainable development and responses to climate change national priorities [69].

- The Climate Change Act (2016) [70], which is the "first framework climate law in Africa" [71] (p. 257). The law requires "the Kenya Institute of Curriculum Development to integrate climate change into various disciplines and subjects of the national education curricula at all levels" [71] (pp. 262-263).

- The Energy Act of 2016. As Stephen Mallowah and Christopher Oyier write, "The Act mandates the government to promote the development and use of renewable energy, including biodiesel, bioethanol, biomass, solar, wind and hydropower, among others" [72].

- The Sustainable Waste Management Bill (2019), which is "An Act of Parliament to establish an appropriate legal and institutional framework for the efficient and sustainable management of waste in the framework of the green economy, the realization of the zero waste goal, the realization of the Constitutional provision on the right to a clean and healthy environment for all, and for connected purposes" [73].

In addition, a number of other action plans and policy papers detail Kenya's approach to climate change and the country's sustainability policies [74-76]. Overall, Kenyan climate legislation is comprehensive and visionary, but implementation lags behind significantly, as the analysis by Clarice Wambua shows [71] (pp. 264-269). 
With regard to education, ESD has been incorporated into the national approach since the early 2000s. (The Kenya Institute of Curriculum Development was established by the government of Kenya on 14 January 2013 under an Act of Parliament. It also evaluates, vets and approves the curriculum and curricular support materials for basic and tertiary education, as well as offers curriculum-based consultancy services for basic and tertiary education and training.) The United Nations declared 2005-2014 the decade of Education for Sustainable Development, and Kenya's approach is outlined in Education for Sustainable Development: Kenya Country Report, 2005-2012 [77]. Regional Centers of Expertise are instituted across the country. The country also has an organizational framework that is dedicated to the promotion of environmental education, the Kenya Organization for Environmental Education [78].

However, the curriculum itself, including assessment, has not yet been overhauled at all levels to reflect the relevance of SDGs for education. In 2014, Petry et al. wrote: "ESD is not currently directly linked to one or more priorities of educational reforms; nonetheless, ESD has the potential of offering transferable skills for both formal and self-employment and it could also make an important contribution to socio-economic development [79]. In 2017, Kenya launched a large-scale curriculum reform that foregrounded a competencebased curriculum (CBC). The policy document includes SDGs in its approach: "Kenya is undertaking a major reform of the national curriculum to produce citizens equipped with relevant and quality knowledge with national values and social competencies and to equip them with the $21^{\text {st }}$ century skills and competencies in line with Kenya Vision 2030, Kenya Constitution 2010 and the Sustainable Development Goals (SDGs)" [80]. While, thus far, the kindergarten levels (K1 and K2) as well as the first four years of primary school curricula have been revised, the last two classes of primary school as well as the following six levels of secondary school education have not. That is, at this point (in 2021), ESDGs have not been integrated officially into most of the curriculum. Furthermore, even if the new curricular plans are finalized, it will take a few years to fully implement the reform. Therefore, similar to the German case, a gap exists between public discourse and implementation into the school curriculum and other parts of the education system.

In light of this persisting gap in the mandatory curriculum regarding ESD, how is ecoliteracy enhanced at secondary schools in Kenya, especially schools that emerged in the context of and continue to be supported by the country's tourism?

\section{Ramifications of Tourism in the Diani-Ukunda Area}

The Diani-Ukunda area on the south coast of Kenya is located in Kwale County, one of the poorer counties in Kenya. In comparison to other areas of Kenya-and for a wide range of political, historical, and cultural factors-Kwale County has been trailing in many areas. The key industry of Diani-Ukunda is tourism, which has grown since the late 1960s and is driven by Diani's spectacular beaches, marine tourism, island destinations, and nearby natural parks. Tens of thousands of tourists stay at the local resorts, hotels, and villas each year. Nevertheless, while Diani-Ukunda is not one of the areas in the country that regularly encounters drought or famine (though the immediate hinterland does), this semi-urban area faces substantial poverty rates as a result of population increase, lack of employment and a weak economic infrastructure. Waste management and access to healthcare, education, water and electricity are among the key sustainability challenges. Anybody who visits the area is exposed to some of these challenges, and, as a result, many tourists are inspired to support locals, in one way or another.

My past research has shown that a large number of Germans, Swiss, and Austrians (among other Europeans) who originally came to Kenya as tourists develop relationships with Kenyans and often support them financially over many years. In some cases, Europeans move to Kenya and establish businesses, including schools. Both personal financial support as well as humanitarian activities generated by expatriates who are active in Kenya affect large numbers of individuals and communities, especially in locations along the coast that are in proximity to centers of tourism. Diani-Ukunda has a wide range 
of educational institutions that are run or co-run by expatriates: a Dutch initiative, the Jan and Ans Verkaart Development Team, has "built more than seventy public primary schools, four public secondary boarding schools for orphaned girls and two polytechnic schools" on the south coast of Mombasa [30] (p. 89). More research is needed to understand the full impact of these educational and also health initiatives driven by Europeans who initially came to the area as tourists; the sustainability of these projects is often tenuous because of the reliance on international donor networks [81]. Fewer private schools are found farther inland, which illustrates the connection of the Diani-Ukunda schools to the lucrative tourism-related infrastructure closer to the beach.

In previous publications, I discussed the nature, extent and often uncertain sustainability of these and other forms of citizen aid (including marriages, other long-term romantic relationships, and various educational and medical organizations) [30]. Over time, my fieldwork showed that environmental sustainability is often a dimension of (in particular) German activities in Kenya. German initiatives are most pronounced in the areas of education and health, and (predominately) German-run and supported schools and health facilities are often equipped with solar panels, eco-toilets, biochar stoves, and other resource-saving equipment. As Germany has been at the forefront of ecological activism and policy implementation, these initiatives reflect the commitment to promoting sustainable practices and ecoliteracy.

A variety of these schools, especially the private ones, that are run or co-run by German expatriates, were founded by individuals who first came to the area as tourists, and are sponsored by a donor network that includes, to a large extent, German visitors to the area. The most visible institutions in this regard are the six schools known as Mekaela Academies, which serve a significant portion of the population of the larger Diani area and beyond. Diani Maendeleo Academy is another reputable institution run by a German expatriate. In the following section, after providing basic information on the schools, I analyze sustainability aspects of the school grounds; extracurricular activities; and results from a survey of the students that shed light on ecological awareness.

\section{Results}

\subsection{Mekaela Academies}

Mekaela Academies originate from the early 1990s. Over the years, founding members Frank Muether (German-born), Micki Wentzel (British-born) and Stefan Wentzel (Germanborn) have overseen the building of four primary and two secondary schools that are located in Mwabungo (to the south of Ukunda), near Diani Beach and near Kombani (about $25 \mathrm{~km}$ north of Ukunda). The four primary schools are the Manuel Alexander School (the first school, which opened in 1996), the Likunda Primary School, the Mekaela Ratinga School and the Mekaela Weber School (the latest addition, in 2019). The two secondary schools are the Lulu High School (an all-boys school that was originally the location of Heshima Primary School) and Lulu Girls High School (added in 2016) [82]. Throughout, the organization received support from German donors, many of whom, like the founders, originally came to the area as tourists and have been visiting the facilities over the years. Since 1996 Watoto e.V., a nonprofit organization in accordance with German laws, has been the main vehicle for donor support (watoto is Kiswahili for "children"). The organization has a considerable fundraising capacity. The most recently added Weber School, for example, was built through a substantial contribution from a private donor from Germany [83]. A fundraising appeal to address the challenges resulting from the coronavirus crisis produced "half of our donation target of 70,000 Euros" within only two weeks [84]. External support was especially important at the time because representatives of the Kenya National Union of Teachers (Knut) fueled resentment against private schools and argued for them to be excluded from government support to alleviate the fallout of the Corona pandemic [85].

Mekaela Academies permanently employ approximately 190 to 200 people (including teachers, gardeners, kitchen staff and security) and is, thus, one of the larger employers in 
the area. The organization is based on a holistic approach to education and the students. Among the various services offered by Mekaela Academies is "free basic medical care through the Mekaela Micro Medical Scheme (MMMS). The children receive outpatient treatment in five surgeries or clinics" [86]. Mekaela also provides career guidance and counseling, including inviting former students and other speakers to share career advice with the students. In 2011, an agency was set up to help unemployed parents and relatives of students locate permanent employment with good working conditions. The schools build on their credibility and on sustained relationships with parents to vouch for the employees' reliability, trustworthiness and overall character. About fifty individuals are employed through Noble Domestic Agency [87] (though Mekaela plans to hand over the Noble Domestic Agency to a new owner, and shift its energies to a new project, the opening of a shoe factory).

Enrollment, as of June 2020, is considerable: 340 at Manuel Alexander School, 550 at Likunda Primary School, 430 at Mekaela Ratinga School, 210 at Mekaela Weber School, 110 at Lulu Girls High School and 130 at Lulu High School. The high schools are boarding schools, and 190 students at the Likunda Primary School are also boarders. About forty percent of the children enrolled in the schools receive scholarships through the organization's fundraising network. Students enrolled at Mekaela Academies have been highly successful, and their achievements stand out in nationwide comparisons. In 2019, "Likunda Primary School came in 7th among the around 1700 primary schools of the Coast Region at the 2019 KCPE exams" [88], a success that was mentioned in the leading national newspaper [89]. Lulu High School ranks in "the Top 100 secondary schools in Kenya (out of approximately 5000)" [90].

The pedagogical framework of the organization is guided by the educational approach of Kurt Hahn, whose ideas outlining the relevance of experiential, expeditionary and project-based learning have been broadly influential, including on the development of curriculum for the International Baccalaureate (IB) Program, in which he participated [91,92]. Experiential, expeditionary and project-based learning is foregrounded in the school's pedagogical approach. These principles resonate with other experience-based pedagogies, including key points articulated by Orr. Orr, for example, suggests that "agriculture should be included as part of a complete liberal arts education" [1] (p. 120). The innovation projects that are key to the Mekaela secondary schools may serve as an example: Students are tasked with being entrepreneurs and innovators by designing a new company, organization, or specific product. Students work through the entire process of innovation, from creating and designing a concept to developing strategies for financial planning and marketing/sales. Many of the projects created by students are ecological, such as the self-flushing toilets designed by one student [93].

Mekaela Academies' emphasis on sustainability is visible through various projects that are on the school grounds and are designed to both increase the sustainability of the schools and raise environmental consciousness:

- Two farms, comprising in total, of twenty-eight acres, provide grain, fruit and vegetables for students and staff, as well as wood for various projects. Students are taught how to plant, grow, maintain and harvest. (Figure 1.)

- The school operates a poultry farm. (Figure 2.)

- An advanced solar power system, donated by the German company Phoenix Solar AG, generates a substantial part of the schools' electricity needs; in fact, Likunda Primary School is almost independent of the grid as a result.

- Mekaela Academies has its own workshop for repairs (including welding and carpentry as well as a tailor shop).

- Energy-saving stoves are used in all kitchens.

- Plastic, glass, metal, and paper are collected on the schools' grounds and brought to a recycling station in Ukunda, where it is sorted.

- Students and employees are encouraged to assist in saving energy by, for example, switching off lights when they are not needed. 
- Casuarina trees, a favorite of sustainable agroforestry, are planted on the school grounds. The fast-growing trees are drought-resistant, salt-resistant, and aid against soil erosion. Mekaela uses the durable wood for building purposes.

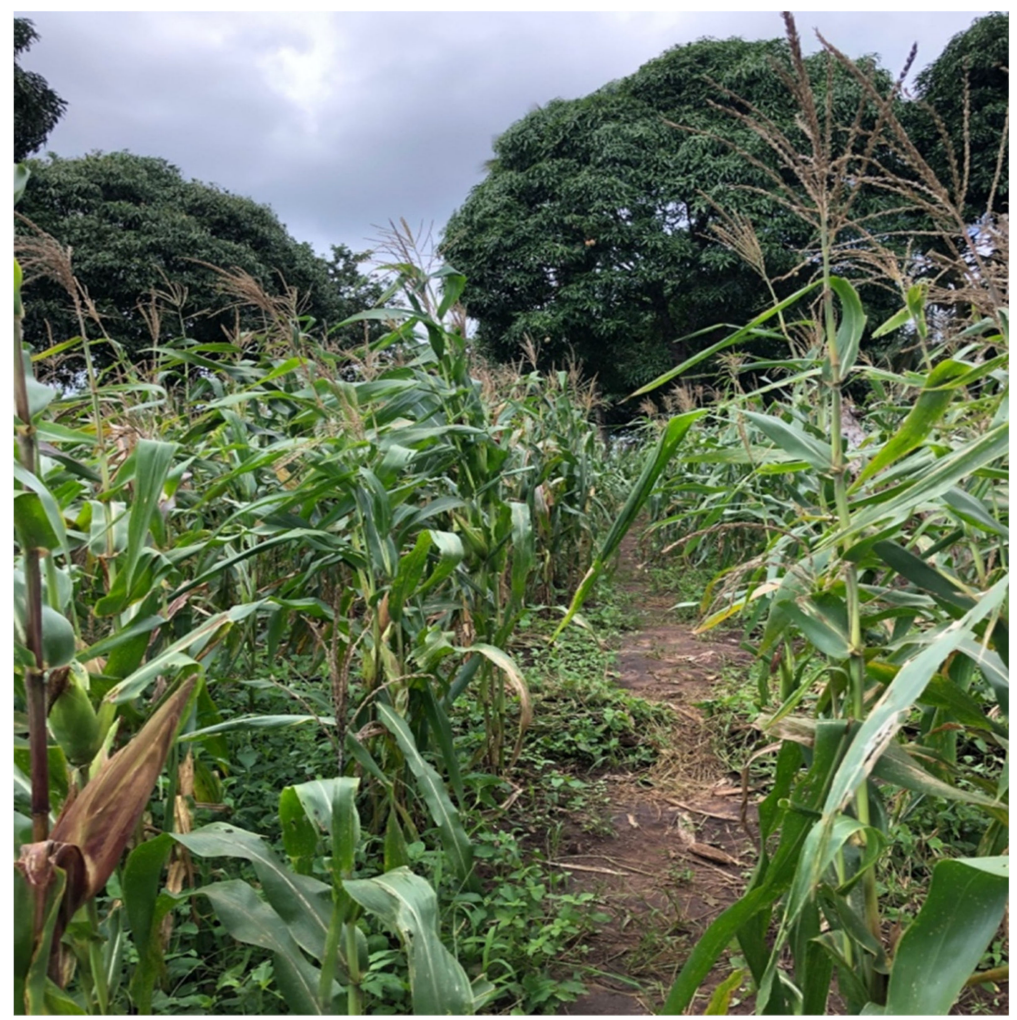

Figure 1. Mekaela Academies: Maize fields and mango trees.

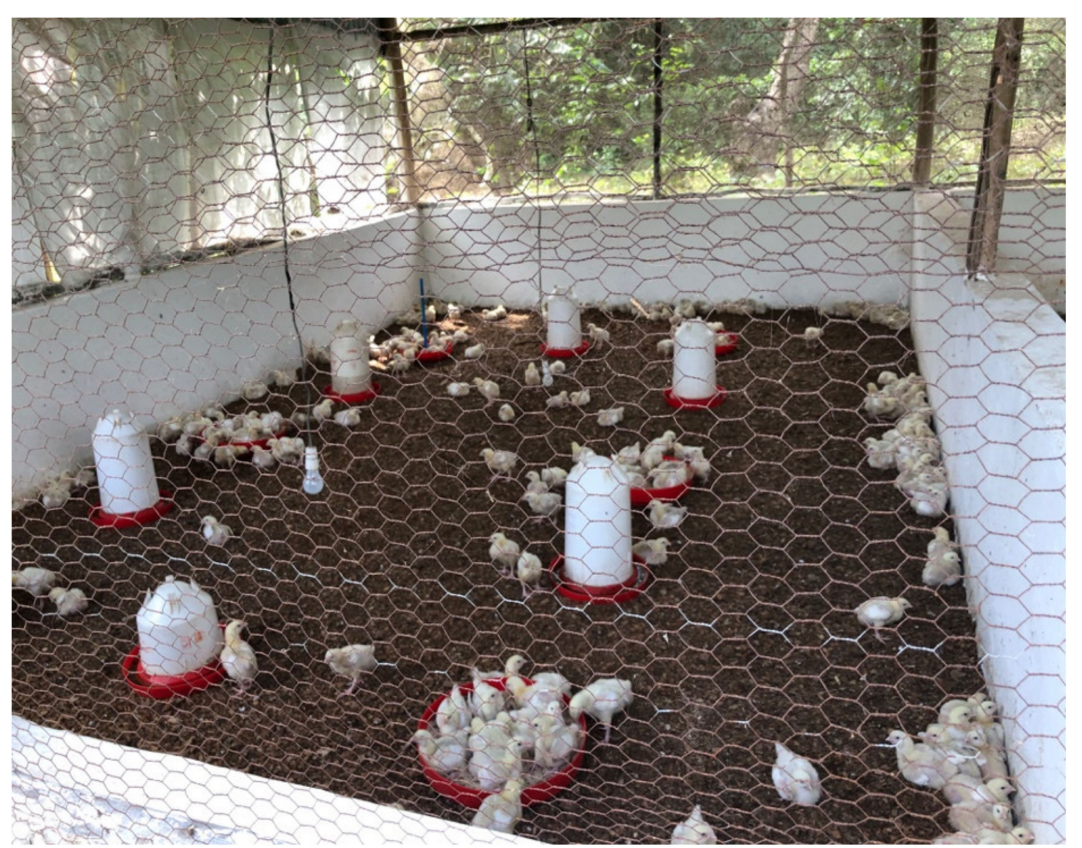

Figure 2. Mekaela Academies: Poultry farm.

Students are thus surrounded by and in constant contact with a wide range of sustainability measures. The various features lend themselves to experiential learning and communicate a holistic approach toward environmental sustainability. 
In terms of extracurricular activities, the schools enable students to choose from a wide variety of clubs, including groups focused on drama, music, first aid (conducted together with the local chapter of the Red Cross), various sports (including karate, jiu-jitsu, and swimming) and journalism. In addition, an environmental club specifically practices environmental learning. Students plant trees and learn how to tend to them; participate in beach clean-ups and turtle watches; learn how to produce less waste and how to make useful things out of waste; and learn about ocean sustainability.

In addition, every year, the organization hosts a cultural week to raise social and ecological awareness and give back to the community. Activities include beach cleanups, Ukunda clean-ups, volunteering at homes for the disabled, donation drives (e.g., mattresses or clothes) and tree planting and other similar events. The cultural week also includes activities related to the cultural practices and histories of Kenya's ethnic groups. Parents are often involved in some of the sustainability activities, such as the clean-up days. Overall, the activities are designed to raise awareness for the natural environment as well as cultural traditions.

While the sustainability curriculum prescribed by the Ministry of Education for Form 1 through 4 (secondary education in the current system) lacks explicit ecoliteracy content and assessments, the schools thus feature a substantial number of initiatives that enhance sustainability and are designed to increase ecoliteracy among students.

\subsection{Diani Maendeleo Academy}

Diani Maendeleo Academy is a private secondary school for girls. Its director, Ingeborg Langefeld, was employed in Germany as a social worker. In 2003 and after having visited the country for eight years as a tourist, she moved to Kenya with a specific plan to create opportunities for female students. Diani Maendeleo Academy is the result of her efforts. At the time, no such institution existed on the advanced level in the predominantly Muslim Diani area. (Research focused on Islam and education in the area, specifically, is scarce. The schools discussed here increase educational opportunities, particularly for girls. Over the past twenty years, I have not observed any risk to education in the area due to radical Islam. While a small segment of the male population is exposed to radicalization, the number of Muslim girls in the schooling system is increasing steadily.) As the managing director of the school, Langefeld has an investor's permit in the area of education, which includes both work and residency permits. Similar to Mekaela Academies, the school is supported by a Germany-based association: The NGO Girls' Hope e.V. promotes the project and raises funds for scholarships, school supplies, and the construction and maintenance of buildings [94]. Langefeld is the chair of the German NGO, which increased its membership from twenty-eight in 2010 to currently forty. The relationship between the German NGO and the Kenyan school is regulated through a contract. Buildings constructed with money from Girls' Hope belong to Girls' Hope, and the NGO also holds first buyer's right for buildings that belong to the school but were not built with funds from Girls' Hope.

The Diani Maendeleo secondary school was founded in 2004 and opened in 2005; its academic reputation has increased every year. By early 2014, one hundred students were enrolled. The highest enrollment was registered at the beginning of 2017, when 144 female students attended the school. However, persistent problems with the head teacher at the time led to many students withdrawing, so that by the end of the year only ninety-eight were left. The situation stabilized gradually, with 115 female students enrolled in 2020. The school is located in the area of Mwabungo, about seven kilometers south of Ukunda. Similar to the Mekaela schools, it serves the larger area, and the addition of the boarding school allows for a larger number of female students to come from farther away. About a quarter of the girls come from nearby Ukunda and other Diani locations; others originate from Mwabungo, Msambweni, Tiwi, Malungoni, Kbarani, Lunga Lunga and Ndavaya. Some of these locations are more than an hour's drive away.

The school is accredited by the Ministry of Education, but as a private school with a donor network, it is primarily financed by donations (eighty-eight percent of its funding in 
2018). Additional funds come in through school fees and contributions from the county. In addition to covering student fees, funds from donations are used to pay for building construction and maintenance, staff salaries and supplies. Financial sustainability has been increased through the addition of a boarding house, which was completed in 2015 and sleeps eighty-eight students. To provide financial transparency, the German NGO posts complete annual financial reports for itself and the school on the web, which is not at all a common practice among these types of charitable institutions [95]. The total amount raised by Girls' Hope over the years has fluctuated between EUR 50,000 to close to EUR 100,000. Over time, local donations for specific projects have made it possible for a kitchen to be built and for a school bus to be acquired.

Girls' Hope raises funds mostly in Germany; it initially drew on Langefeld's personal networks in Gelsenkirchen and Mülheim and then broadened its geographical range over time. Donations are obtained in various ways, including the fundraising platform Bildungsspender, the Futura Foundation, Soroptimist International and individual donors. In 2010, Girls' Hope supported fifty-one of the eighty students at Diani Maendeleo through fellowships; by 2020, ninety-six of 115 students were sponsored through fellowships (83\%). The four classrooms each have a capacity of forty-five, allowing for a total enrollment of 180 students. Increasing enrollment to the level of 2017 is one of Langefeld's current goals, because it would make the school more viable.

Conceptually, the school is inspired by human rights demands in the area of education and gender equality. In a conversation with me in February 2010, Langefeld emphasized that learning is a "human right: everyone has the right to learn." "Modern Education based on Traditional Roots" is printed on the school bus, along with the following sentence: "No one can go back and make a new beginning/But anyone can start from now and make a happy ending." This call for individual agency alongside solidarity is reflected in another school slogan: "Many small people in many small places who take many small steps can change the face of the world." The school aims to promote the full participation of women in Kenyan society. Related to this goal is the fact that the school provides free breakfast and lunch for all students. This policy developed after the realization that students from poorer backgrounds were often arriving to school hungry. In the school's 2013 report, Langefeld wrote, "We consider good meals as just as important as good academic instruction" [96].

In addition to its support of gender equality, better education, self-empowerment, and solidarity, Diani Maendeleo Academy aims to foster knowledge of ecology and sustainability. An initial conversation over Skype on 12 May 2020 about ecoliteracy with the head teacher, Madame Kemunto, suggested a high level of awareness of ESDGs. Seven of the school's teachers, including the head teacher, participated in a meeting that took place on 18 May 2020 to discuss how ESDGs were included in the curriculum. In spite of the lack of mandatory guidelines on this subject, the teachers were clearly aware of the various Kenyan initiatives regarding sustainable development. In notes taken at the meeting, they listed "National guidelines on education for sustainable one planet network; Education for sustainable development (ESD); Kenya country report (NEMA); Guidelines on education policy for sustainable built environment; A guide to mainstreaming education for sustainable development (UNESCO); Republic of Kenya ministry of environment, water and natural resources; Republic of Kenya environment action plan preparation guidelines, posted on Relief web; Guides for sustainable schools in UNECE.; M.O.D education for sustainable development policy for education." They all described ways in which specific content they were teaching was related to ESDGs. The teacher responsible for Kiswahili, for example, reported that writing compositions on the importance of trees were included in instruction and assessment in Forms 1 and 2 and that a writing assignment on conservation of the environment was integrated into the curriculum for Forms 3 and 4. The biology teacher reported that a unit on ecology and the preservation of the environment, including the relevance of biogas, was part of the curriculum for Form 3. Teachers responsible for business studies, religion, agriculture, geography, physics, chemistry, English, and math- 
ematics all provided evidence of the inclusion of ESDGs in the curriculum. In a written document that was shared with me, teachers also provided the following assessment goals:

"The following are examples of goals for assessments

- The learner should be able to conserve the environment

- The learner should understand the causes and effects, consequences

- To know the natural resources distribution

- To identify the climatic changes

- To acquire knowledge of their surrounding

- To describe their ecosystem

- To describe the issues/sustain food security

- To maintain environmental health."

Because ESD will be integrated into the curriculum over the next few years through the current school reform, future studies will be able to assess the degree to which these learning objectives are reached.

The teachers also pointed to the various projects that distinguish Diani Maendeleo's integrated approach to sustainability. I will provide an overview of these and other initiatives that reflect the school's approach to sustainability. While enhancing the school's sustainability has a financial motivation (to decrease costs and reliance on outside revenue), the various initiatives are also part of an integrated approach to teaching ecological skills to the students. Diani Maendeleo, similar to Mekaela Academies, has developed a number of sustainability measures:

- All roofs have been equipped with water spouts for rainwater collection and are connected to the school's twelve water tanks. (Figure 3.)

- Solar panels have been attached to six roofs.

- The Solar Water Disinfection (SODIS) project teaches the students how to produce drinkable water. The technology was developed in the early 1990s and involves waterfilled plastic bottles that are exposed to solar radiation, whereby the ultraviolet light kills bacteria and makes the water potable [97].

- $\quad$ There are eight EcoSan dry toilets on the school's compound [98]. (Figure 4.)

- The school has a goal to collect all plastic, glass, paper, and metal and bring them to a recycling station in Ukunda.

- Diani Maendeleo grows sukuma, a type of spinach, and cassava on a field behind the school

- In 2013, the school added a fishpond to generate income from the sale of fish. The project, which was funded by the Ministry of Fisheries Development, has not been successful to date; a regular buyer for the harvested fish could not be found and the harvest was often diminished because of theft and other factors (lack of funds for repairs). Presently, the agricultural teacher is charged with addressing these challenges to make the pond viable again. In the meantime, the project still functions as an educational tool.

- In order to increase the availability of food for school meals, Langefeld acquired a greenhouse in 2012. Similar to the fish pond, it is presently non-functional due to the reduced availability of funds resulting from the COVID-19 crisis.

Several of these measures face significant challenges: The agricultural projects are threatened by wild pigs and monkeys, the fish pond needs to be maintained by a more knowledgeable staff member, the students need to be repeatedly instructed on how to use the EcoSan toilets, and the sorting of recycling is a constant battle. However, overall, Diani Maendeleo's students, similar to those at Mekaela, are surrounded by and engage with various forms of sustainability measures.

In terms of extracurricular activities, Diani Maendeleo features the Interact Club, which is supported by the Kwale Rotary Club and officially registered as a Rotary Youth organization. At club meetings, students are taught, for example, how to clean the SODIS project bottles and how to recycle. The Interact Club also participates in community and 
beach clean-up events. Students are also engaging in recycling drives by collecting and sorting waste. Over the years, the students have discussed the benefits of solar and wind technology, made soap from neem leaves, assisted in medical camps and participated in various social projects. Diani Maendeleo also hosts a chapter of the Girl Scouts, and some of their activities are also dedicated to the environment, mirroring the activities of the Interact Club. The very popular Agriculture Club, led by one of the school's teachers, was lacking good leadership for many years; in fact, to the chagrin of the director, one teacher was using pesticides and other chemicals. The current teacher is focusing on sustainable practices, such as teaching students how to compost.

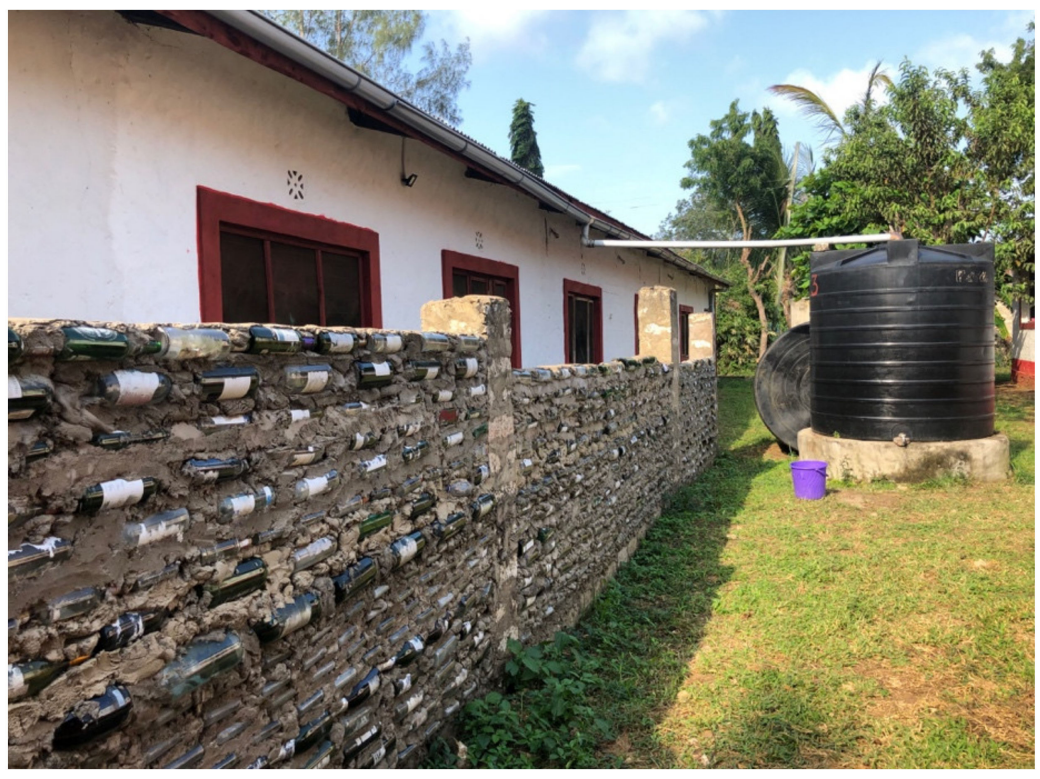

Figure 3. Maendeleo Academies: Rainwater catchment tank and wall built with recycled glass bottles.

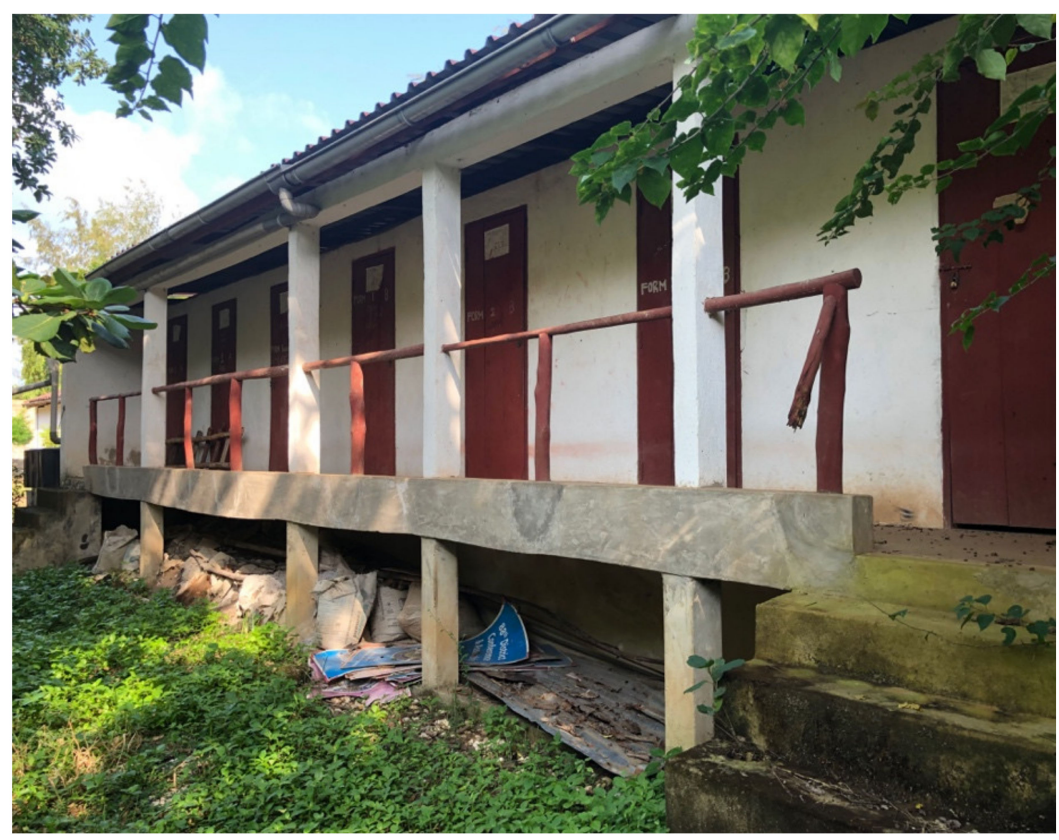

Figure 4. Maendeleo Academies: EcoSan dry toilets.

In addition to the ecoliteracy content of the current curriculum, Diani Maendeleo and Mekaela Academies thus pursue a holistic approach to enhancing ecoliteracy through 
their various sustainability projects and extracurricular activities. What level of ecological consciousness did students express when prompted to respond to questions designed to assess ecoliteracy?

\subsection{Results from Survey Instruments}

Given the limitations to fieldwork in a year that did not allow for international travel, research was conducted digitally to assess ecoliteracy awareness among the students at the two schools. Questions addressed issues of waste, diet, agriculture, water, environmental projects (in the case of Diani Maendeleo), global warming and climate activism. The survey instrument for Diani Maendeleo was dichotomous and multichotomous: Students circled Yes/No responses as well as marked multiple options to some of the questions. The survey instrument for Mekaela Academies was open-ended. Clearly, both questionnaires only provide insight with regard to awareness and self-assessment, rather than actual practices. Students may have responded according to what they thought the expected response might be, rather than reflecting on their actual behavior (e.g., recycling). The responses thus reflect awareness, rather than behavior. Future in-person interviews, participant observation research, and comparative research (e.g., assessing the situation at additional private and public schools) will provide a deeper understanding in this regard.

\subsubsection{Diani Maendeleo Academy}

Diani Maendeleo returned forty-seven completed questionnaires, which document the views held by about half of the enrolled female students. The first question asked students whether they recycled plastic, for which twenty-two circled "Yes" and twenty-five responded "No." The more general question about putting trash into trash cans or bins showed that half of the students either never (two) or sometimes (twenty-two) disposed trash into cans, while the other half responded that they most of the time (eleven) or always (twelve) disposed of trash that way. Overall, half of the students indicated that they do not recycle and/or properly dispose of trash (with a potentially even higher percentage displaying this behavior in actuality). What is noteworthy, here, is that burning waste is often considered a form of recycling (phone interview with resident of Diani, August 2020), which suggests that some of the student responses about recycling may in fact be tied to these practices. When asked who was responsible for creating and for solving the waste problem in Kenya, only seventeen students indicated that they considered themselves to be responsible. Most indicated that citizens (thirty-five) and the government (twenty-four) created the problem, while the responsibility for solving the problem was mostly assigned to the government (thirty-six), the citizens (twenty-six), and also to industries (seventeen). While some students may have counted themselves among the citizenry, the low number of students who directly took responsibility for creating and solving the waste problem resonates with the lower percentage of those who recycle and dispose of garbage.

Students were asked whether they ate "a healthy diet," and thirty-eight responded in the affirmative. The question, however, was too broad to draw any conclusions, and so the eight students who indicated that their diet was not healthy may have, in fact, a higher level of awareness in this regard, rather than eating a diet that is de facto less healthy than that of the other students. Thirty-eight students indicated that they knew how to plant and harvest fruits and vegetables, while nine said they did not. Thirty-five students indicated that they plant and harvest; twelve said they did not participate in these activities. Almost all students agreed that agriculture should be taught in schools (forty-five; one did not agree) and that schools should have agriculture clubs (forty-three; four did not agree).

Two of Diani Maendeleo's resource-saving projects were also included in the questionnaire. Two-thirds of the students knew that the SODIS project "creates drinkable water" (twenty-nine), while fourteen indicated wrongly that it "helps to reduce water consumption." The EcoSan toilets were very well understood, and only nine students indicated that they were "difficult to use" and five said they were "a problem," while thirty-six indicated that they were "good for the environment" and seventeen that they 
"reduce water consumption." While some students may not be as familiar with the term "SODIS," the responses to the EcoSan toilets suggest that students are largely familiar with the benefits of these projects and feel comfortable using them.

In terms of climate change and global warming, forty students agreed that climate change is affecting Kenya, while six did not agree. Thirty-one thought that Kenya was contributing to global warming; fifteen did not agree with that statement. Responsibility for climate change was attributed to the world (thirty-eight), Kenya (eighteen), China (nine), the United States (seven) and Europe (four). This question allowed multiple responses ("circle all that apply"), and, together with the responses to the questions about climate change and global warming, suggests that more education is needed on these matters. Students, however, were clearly familiar with the term "sustainable development," which thirty-six students considered "important," six a "life saver," and four "somewhat important." None of the students stated that it was "not really important." In terms of climate activism, only sixteen students knew that Greta Thunberg is "a climate activist from Sweden." Thirty-seven students, however, knew that Wangari Maathai was "a climate activist from Kenya."

\subsubsection{Mekaela Academies}

A total of forty-seven questionnaires were completed by students from Mekaela Academies (a smaller segment of the overall students, in comparison to Diani Maendeleo), among them, eleven male and thirty-six female students, ranging from fourteen to twenty years of age. Students at Mekaela were asked to respond to eight open-ended questions. Some differences are apparent when comparing responses from male students to those of female students. For example, almost all female students were able to name five trees growing in their area, while only one boy listed five trees. Only five of thirty-six female students listed less than four, while six of the eleven male students listed less than four. Responses to the question about whether students knew where their water came from showed a high level of awareness. The majority named boreholes, wells, specific rivers, springs and dams. Two female students who seemed to originate from urban areas listed "tap" and one did not respond; a male student wrote "from the Kenya water supply company" and another wrote "Kwale water pipe line."

Similarly, responses to the question about where their garbage went reflected a high level of awareness for their immediate environment. Nine of the eleven male students gave a specific response and named the dump site or stated that they were burning trash (one) or depositing it in a pit (one). Two did not respond. Of the thirty-six female students, four did not respond (two from urban areas); the rest named specific sites or stated that trash was burned. Six female students made a distinction between compost, recyclables, and other trash, thus expressing awareness about the separation of garbage. All students responded to the question "In what ways do you contribute to protecting the environment?" Most listed several activities, but eleven female and two male students listed only one. Planting trees, properly disposing of waste, not burning plastics, recycling plastic, reusing materials, participating in community clean-ups, watering plants and "educating the people on the importance of protecting the environment" were among the responses.

With regard to questions that solicited science-based input, more male than female students provided responses. For example, the question "What are the reasons for global warming?" was not answered by one male and ten female students. Deforestation was mentioned in most responses, followed by $\mathrm{CO}_{2}$ emissions, burning of fossil fuels and agriculture. Many students named more than one reason. Regarding the question "How could affordable power be made available to all Kenyans?", ten female students did not respond. Three responses were slightly off topic and two of those seemed copied off the internet. Other responses, however, focused on increasing solar power, biogas, and other renewable energies. Two male students did not answer the question; all others named one or more renewable energy sources, such as solar power, geothermal power, wind energy, and hydroelectric power. One male student suggested "inventing cheap ways of energy 
production." One female student suggested "Using free energy from the earth. Research free energy by Nikola Tesla."

Replies to the question "Who is responsible for protecting the environment?", mirrored a high level of awareness of civic duties. All male students responded and stated that "everyone," "Kenyan citizens," "all people, "everyone including me," or "each and every single person living on planet earth" was responsible. Two of the female students did not respond, one female student copied part of a statement about the role of the EPA (the U.S. Environmental Protection Agency), and four female students focused on their most immediate environment ("Students, Mr. Hassan" and "People I live with and myself"). Everybody else offered up views that mirrored those of the male students. As one female student wrote, "I am responsible, you are responsible, we are responsible, everyone is responsible."

Almost everybody responded to the last question, "Who is Wangari Maathai?" Only three female students did not respond. For example, one of the male students wrote, "A Kenyan lady who fought for conservation of trees. She was beaten und suffered but didn't lose hope." Another wrote, "She was an activist on conservation of trees. She used to live in Nairobi." A female student wrote, "An environmentalist who was very active in planting of trees." While the explanations given by the male students varied a great deal (all largely correct), about half (fifteen) of the female students inserted the same sentence from the Wikipedia article on Maathai, or a version thereof ("Wangarĩ Muta Maathai was a renowned Kenyan social, environmental and political activist and the first African woman to win the Nobel Prize" [99]).

\section{Discussion: Main Takeaways}

Responses to questionnaires completed by students from the two schools clearly demonstrate a substantial level of awareness and positive disposition regarding their immediate environment (trees, waste, water, agriculture). The familiarity with the local context and deep understanding of agricultural practices presents an opportunity for integration into education for sustainable development, especially food culture. Waste management and recycling, however, clearly continue to be challenge areas. The fact that so many students from Mekaela Academies indicated that they were burning their waste (which, as stated before, is often seen as a form of recycling), combined with the low level of recycling practices as indicated in the responses from the Diani Maendeleo students, suggests that recycling is not the norm.

Students also displayed a substantial understanding of global warming, climate change and sustainable energy practices. They are familiar with basic vocabulary, and about two-thirds of the responses offered insight based on factual information. The gender differences in the responses from Mekaela Academies are worth pursuing, as are the apparent signs that students from urban areas are less familiar with questions related to water and waste than those from the coast. A distinct difference between Mekaela Academies and Diani Maendeleo surfaced with regard to who is responsible for protecting the environment and solving the waste problem. Students at Mekaela unanimously embraced that responsibility to protect the environment by including themselves in the open-ended responses, while only seventeen out of forty-seven Diani Maendeleo students considered themselves responsible for solving the waste problem. Student responses to the survey instruments thus indicate that both Mekaela Academies and Diani Maendeleo have succeeded in instilling a substantial level of ecoliteracy in their students, in areas ranging from students' immediate natural environment to their understanding of global processes.

As seen in this analysis of two private schools, both of which emerged within and are sustained to a great extent by ripple effects of tourism, the Mekaela Academies and Diani Maendeleo Academy integrate sustainable practices into the broader conceptual frameworks of the schools. Sustainability has a place not only in the mandatory curriculum (rudimentary to-date), but is integrated into the basic infrastructure of the school compounds, ecological practices (energy conservation, EcoSan toilets), as well as a wide 
range of extracurricular activities. In their holistic approach, the schools address most of the SDGs that are specifically focused on the environment: clean water and sanitation (6), affordable and clean energy (7), climate action (13), life below water (14), and life on land (15). Goal \#17, "Partnerships for the goals," is present through the fact that these schools are supported by local and global north donor networks and collaborate in environmental action days with other local organizations.

Overall, it can be inferred that the integrated approach toward teaching ecoliteracymandatory curriculum, infrastructure of the schools, ecological practices, and extracurricular activities-delivers considerable outcomes. While the Kenyan educational sector is awaiting the explicit integration and implementation of ESD into the curriculum, schools across the country are taking matters into their own hands. The large number of sustainability initiatives and activities that are integral to the institutions and available to students at both Mekaela and Diani Maendeleo, in conjunction with the curriculum proper (which to-date does not include a systematic approach to teaching ESDGs), successfully generate ecological awareness among the students. The mixed method approach pursued in this study illustrates the interrelations between socioeconomic and historical factors (especially the connection to tourism), educational curricula, the sustainability initiatives and practices on the compounds, and the evidence for students' ecological consciousness; the missing link, however, is the broader application of that consciousness in practice. Follow-up studies are needed to explore this dimension. In addition, comparative research needs to be conducted to better understand the levels of ecoliteracy at the select schools documented here in comparison to those at other private and public schools. The results from mixed method research presented in this study (including interviews, survey instruments, scholarship review, long-term study of the area) provide a baseline that can be useful to further comparative and long-term investigations.

\section{Increasing Ecoliteracy: A Ripple Effect of Tourism on the Kenyan Coast}

Funds sent by German and other European citizens, many of them former and repeat tourists to the area, support both the Mekaela Academies and Diani Maendeleo in substantial ways. As such, the schools exemplify inspiring models of global solidarity in the area of education for sustainable development, an area of education that has recently increased in relevance and urgency, confirming Munsters's (among others) argument about the potentially positive effect of tourism on local cultures [30]. The questions addressing responsibility, as included in the questionnaires, touched upon a central dimension of ecoliteracy that is crucial for the creation of sustainable futures. Consciousness-raising in this regard is key to ensuring that our planet remains habitable for humans and other species. As the global youth movement shows, young humans from across the planet are insisting on their right to a habitable planet. However, centuries of global power relations have produced attitudes in the global south that can function as impediments to creating sustainable practices. Dependency on foreign aid and humanitarianism, paired with the desire to follow in the footsteps of Western developmentalism, often presents barriers to ecological practices. To break these centuries-old patterns, some ripple effects of tourism may inspire new models of collaboration, especially as critics of tourism insist that tourism has to be sustainable and rooted in solidarity with and respect for local cultures. Building the trust that is essential to solidarity-based relations and respect, however, takes time; yet, the need for a global consciousness of solidarity and collaborative innovative solutions is urgent. German/European-Kenyan initiatives, as evidenced in these select schools in Kenya, can be infused with ecological activism and can demonstrate much-needed ethics of global solidarity in approaches toward the Kenyan environment. As Rebecca Solnit extensively documents in A Paradise Built in Hell, disaster can be the seed for opportunity and healing. As humans across the planet increasingly face ecological disasters, new patterns of global solidarity are emerging [100]. 
Funding: The study was supported through research funds from Arizona State University.

Institutional Review Board Statement: The study was conducted according to the guidelines of the Declaration of Helsinki, and approved by the Institutional Review Board of Arizona State University, protocol code STUDY00012080, on 7 February 2020.

Informed Consent Statement: Informed consent was obtained from all subjects involved in the interviews. Consent was waived for the survey that was conducted digitally and was anonymous.

Acknowledgments: I would like to thank Kimberly Koerth and Matthew Pascucci for their careful editorial review of this essay. I would also like to thank Joni Adamson and Mary A. Otieno, who provided valuable input on the survey instruments and an earlier version of this article.

Conflicts of Interest: The author declares no conflict of interest.

\section{References}

1. Orr, D.W. Earth in Mind: On Education, Environment, and the Human Prospect; Island Press: Washington, DC, USA, 1994.

2. Lenzen, M.; Sun, Y.; Faturay, F.; Ting, Y.; Geschke, A.; Malik, A. The carbon footprint of global tourism. Nat. Clim. Chang. 2018, 8, 522-528. [CrossRef]

3. Ehigiamusoe, K.U. Tourism, growth and environment: Analysis of non-linear and moderating effects. J. Sustain. Tour. 2020, 28, 1174-1192. [CrossRef]

4. $\quad$ Robinson, R.N.S.; Martins, A.; Solnet, D.; Baum, T. Sustaining precarity: Critically examining tourism and employment. J. Sustain. Tour. 2019, 27, 1008-1025. [CrossRef]

5. Oxford English Dictionary. "Ecotour, n.," “Ecotourism, n." OED Online. June 2021. Oxford University Press. Available online: http:/ / www.oed.com/viewdictionaryentry/Entry/11125 (accessed on 8 June 2021).

6. Statista. Market Size of the Ecotourism Sector Worldwide in 2019, with a Forecast for 2027. Available online: https://www. statista.com/statistics/1221034/ecotourism-market-size-global (accessed on 25 July 2021).

7. Lewis, S.M.; Thancharoen, A.; Wong, C.H.; López-Palafox, T.; Velasco Santos, P.; Wu, C.; Faust, L.; De Cock, R.; Owens, A.C.S.; Lemelin, R.H.; et al. Firefly tourism: Advancing a global phenomenon toward a brighter future. Conserv. Sci. Pract. 2021,3, e391. [CrossRef]

8. Leonard, L.; Musavengane, R.; Siakwah, P. (Eds.) Sustainable Urban Tourism in Sub-Saharan Africa: Risk and Resilience; Routledge: New York, NY, USA, 2020.

9. Higgins-Desbiolles, F.; Wijesinghe, G. The critical capacities of restaurants as facilitators for transformations to sustainability. J. Sustain. Tour. 2019, 27, 1080-1105. [CrossRef]

10. Dinica, V. The environmental sustainability of protected area tourism: Towards a concession-related theory of regulation. $J$. Sustain. Tour. 2018, 26, 146-164. [CrossRef]

11. Iakovoglou, V.; Zaimes, G.N. Enhancing rural areas while safeguarding ecosystems through sustainable practice of ecosystem based approaches (EBA) with emphasis on ecotourism. Int. J. Bio-Resour. Stress Manag. 2018, 9, 129-131. [CrossRef]

12. Barnett, A.; Abrantes, K.G.; Baker, R.; Diedrich, A.S.; Farr, M.; Kuilboer, A.; Mahony, T.; McLeod, I.; Moscardo, G.; Prideaux, M.; et al. Sportfisheries, conservation and sustainable livelihoods: A multidisciplinary guide to developing best practice. Fish Fish. 2016, 17, 696-713. [CrossRef]

13. Noriega, J.A.; Zapata-Prisco, C.; García, H.; Hernández, E.; Hernández, J.; Martínez, R.; Santos-Santos, J.H.; Pablo-Cea, J.D.; Calatayud, J. Does ecotourism impact biodiversity? An assessment using dung beetles (Coleoptera: Scarabaeinae) as bioindicators in a tropical dry forest natural park. Ecol. Indic. 2020, 117, 106580. [CrossRef]

14. Brandt, J.S.; Buckley, R.C. A global systematic review of empirical evidence of ecotourism impacts on forests in biodiversity hotspots. Curr. Opin. Environ. Sustain. 2018, 32, 112-118. [CrossRef]

15. Potvin, D.A.; Anderson, M.K.; Levengood, A.L. Effects of ecotourism on eastern yellow robin (Eopsaltria australis) vocal behaviour. Aust. J. Zool. 2020, 68, 1-8. [CrossRef]

16. Tauro, A.; Ojeda, J.; Caviness, T.; Moses, K.P.; Moreno-Terrazas, R.; Wright, T.; Zhu, D.; Poole, A.K.; Massardo, F.; Rozzi, R. Field Environmental Philosophy: A Biocultural Ethic Approach to Education and Ecotourism for Sustainability. Sustainability 2021, 13, 4526. [CrossRef]

17. Holland, K.K.; Larson, L.R.; Powell, R.B.; Holland, W.H.; Allen, L.; Nabaala, M.; Tome, S.; Seno, S.; Nampushi, J. Impacts of tourism on support for conservation, local livelihoods, and community resilience around Maasai Mara National Reserve, Kenya. J. Sustain. Tour. 2021, 1-23. [CrossRef]

18. Mayaka, M.; Croy, W.G.; Cox, J.W. Participation as motif in community-based tourism: A practice perspective J. Sustain. Tour. 2018, 26, 416-432. [CrossRef]

19. Deisser, A.; Njuguna, M. (Eds.) Conservation of Natural and Cultural Heritage in Kenya: A Cross-Disciplinary Approach; UCL Press: London, UK, 2016.

20. Nthiga, R.W.; Van der Duim, R.; Visseren-Hamakers, I.J.; Lamers, M. Tourism-conservation enterprises for community livelihoods and biodiversity conservation in Kenya. Dev. S. Afr. 2015, 32, 407-423. [CrossRef] 
21. Honey, M. Community conservation and early ecotourism: Experiments in Kenya. Environ. Sci. Policy Sustain. Dev. 2009, 51, 46-57. [CrossRef]

22. Nyamweru, C.; Kimaru, E. The contribution of ecotourism to the conservation of natural sacred sites: A case study from coastal Kenya. J. Study Relig. Nat. Cult. 2008, 2, 327-350. [CrossRef]

23. Koiyaki Guiding School. Available online: https://www.outsidego.com/africa-conservation/koiyaki-guiding-school (accessed on 25 July 2021).

24. Lion Guardians. Available online: http:/ /lionguardians.org (accessed on 25 July 2021).

25. Ali, I. Kenyan children's ideas about parks and wildlife. Environ. Educ. Res. 2002, 8, 439-462. [CrossRef]

26. Quigley, C.F.; Miller, Z.D.; Dogbey, J.; Che, S.M.; Hallo, J. 'No One Should Destroy the Forest': Using photo-based vignette interviews to understand Kenyan teachers' views of the environment. Int. J. Sci. Educ. 2014, 36, 2937-2957. [CrossRef]

27. Namunga, N.W.; Otunga, R.N. Teacher education as a driver for sustainable development in Kenya. Int. J. Humanit. Soc. Sci. 2012, 2, 228-234.

28. Macharia, M.; Kimani, N. Early Childhood Education for Sustainable Development in Kenya; Siraj-Blatchford, J., Mogharreban, C., Park, E., Eds.; International Research on Education for Sustainable Development in Early Childhood Series; Springer: Cham, Switzerland, 2016; pp. 59-76. [CrossRef]

29. Berman, N. Germans on the Kenyan Coast: Land, Charity, and Romance; Indiana University Press: Bloomington, IN, USA, 2017.

30. Munsters, W. Culture and tourism: From antagonism to synergism. Ido Mov. Cult. 2008, 8, 165-173.

31. Misiaszek, G.W. Ecopedagogy: Critical Environmental Teaching for Planetary Justice and Global Sustainable Development; Bloomsbury: London, UK, 2020.

32. Goleman, D.; Bennet, L.; Barlow, Z. Ecoliterate: How Educators are Cultivating Emotional, Social, and Ecological Intelligence; JosseyBrass: San Francisco, CA, USA, 2012.

33. Kahn, R. Critical Pedagogy, Ecoliteracy, E Planetary Crisis: The Ecopedagogy Movement; Peter Lang: New York, NY, USA, 2010.

34. Stone, M.K.; Barlow, Z. (Eds.) Ecological Literacy: Educating Our Children for a Sustainable World; Sierra Club: San Francisco, CA, USA, 2005.

35. Center for Ecoliteracy. Available online: https:/ / www.ecoliteracy.org/about (accessed on 25 July 2021).

36. Sustainable Development Goals. Available online: https:/ / sustainabledevelopment.un.org/sdgs (accessed on 25 July 2021).

37. Impact Rankings 2020. Available online: https:/ / www.timeshighereducation.com/rankings/impact/2020/overall\#! / page/0/ length/25/sort_by/rank/sort_order/asc/cols/undefined (accessed on 25 July 2021).

38. Kwale County Government. Available online: https://kwalecountygov.com/kwale/index.php?option=com_content\&view= featured\&Itemid=435 (accessed on 25 July 2021).

39. Richards, G.; Munsters, W. (Eds.) Cultural Tourism Research Methods; CABI: Oxfordshire, UK, 2010.

40. Hesse-Biber, S.N.; Johnson, R.B. (Eds.) The Oxford Handbook of Multimethod and Mixed Methods Research Inquiry; Oxford University Press: New York, NY, USA, 2015.

41. Uekötter, F. The Greenest Nation? A New History of German Environmentalism; The MIT Press: Cambridge, MA, USA, 2014.

42. Pettenkofer, A. Die Entstehung der grünen Politik: Kultursoziologie der westdeutschen Umweltbewegung; Campus: Frankfurt am Main, Germany, 2014.

43. Dürbeck, G.; Stobbe, U.; Zapf, H.; Zemanek, E. (Eds.) Ecological Thought in German Literature and Culture; Lexington Books: Lanham, MD, USA, 2017.

44. UNESCO. Roadmap for Implementing the Global Action Programme on Education for Sustainable Development; United Nations Educational, Scientific and Cultural Organization: Paris, France, 2014; Available online: https://sustainabledevelopment.un.org/ content/documents/1674unescoroadmap.pdf (accessed on 25 July 2021).

45. Singer-Brodowski, M.; Brock, A.; Etzkorn, N.; Otte, I. Monitoring of education for sustainable development in Germany-Insights from early childhood education, school and higher education. Environ. Educ. Res. 2019, 25, 492-507. [CrossRef]

46. Bundesministerium für Umwelt, Naturschutz und nukleare Sicherheit, Umwelt im Unterricht. Available online: https://www. umwelt-im-unterricht.de/themen/klima/klima-das-thema-im-ueberblick/ (accessed on 25 July 2021).

47. Bundesministerium für Bildung und Forschung, Lernmaterialien. Available online: https://www.bne-portal.de/de/ lehrmaterialien (accessed on 25 July 2021).

48. Hessisches Kultusministerium, Bildungsstandards, Kerncurricula und Lehrpläne. Available online: https://kultusministerium. hessen.de/schulsystem/bildungsstandards-kerncurricula-und-lehrplaene-0 (accessed on 25 July 2021).

49. Senatsverwaltung für Bildung, Jugend und Familie, Rahmenlehrpläne. Available online: https://www.berlin.de/sen/bildung/ unterricht/faecher-rahmenlehrplaene/rahmenlehrplaene/ (accessed on 25 July 2021).

50. Nilgens, J. Umwelterziehung in der Grundschule: Grundlagen und unterrichtspraktische Anregungen; Disserta Verlag: Hamburg, Germany, 2014.

51. Incedal, U. Umwelterziehung in Schulen. Szenario-Technik oder Zukunftswerkstatt? GRIN Publishing: Munich, Germany, 2015.

52. Bormann, I.; Nikel, J. How education for sustainable development is implemented in Germany: Looking through the lens of educational governance theory. Int. Rev. Educ. 2017, 63, 793-809. [CrossRef]

53. Sprenger, S.; Nienaber, B. (Education for) Sustainable development in geography education: Review and outlook from a perspective of Germany. J. Geogr. High. Educ. 2018, 42, 157-173. [CrossRef] 
54. Kolleck, N. Uncovering influence through social network analysis: The role of schools in education for sustainable development. J. Educ. Policy 2016, 31, 308-329. [CrossRef]

55. Singer-Brodowski, M.; Brock, A.; Grund, J.; de Haan, G. Reflections on the science-policy interface within education for sustainable development in Germany. Environ. Educ. Res. 2021, 27, 554-570. [CrossRef]

56. Niedlich, S.; Kummer, B.; Bauer, M.; Rieckmann, M.; Bormann, I. Cultures of sustainability governance in higher education institutions: A multi-case study of dimensions and implications. High. Educ. Q. 2020, 74, 373-390. [CrossRef]

57. Filho, W.L.; Frankenberger, F.; Salvia, A.L.; Azeiteiro, U.; Alves, F.; Castro, P.; Will, M.; Platje, J.; Lovren, V.O.; Brandli, L.; et al. A framework for the implementation of the Sustainable Development Goals in university programmes. J. Clean. Prod. 2021, 299, 126915. [CrossRef]

58. Hughes, L.; Rogei, D. Feeling the heat: Responses to geothermal development in Kenya's Rift Valley. J. East. Afr. Stud. 2020, 14, 165-184. [CrossRef]

59. The Green Belt Movement. Available online: https:/ / www.greenbeltmovement.org (accessed on 25 July 2021).

60. Hydroponics Africa: Cheap and Sustainable Farming Without Soil. Available online: https://www.hydroponicsafrica.org/aboutus/ (accessed on 25 July 2021).

61. Kings Biofuels Limited. Available online: http://www.kingsbiofuels.co.ke/?fbclid=IwAR0Cg71OuwZiB60iNjzZwAn0A1N-zj1QUqu1uvF87juE9qj6If900puJ8I (accessed on 25 July 2021).

62. Twiga Foods Ltd. Available online: https:/ / twiga.com (accessed on 25 July 2021).

63. Wheeling Fruits. Available online: https://www.lab-of-tomorrow.com/wheeling-fruits (accessed on 25 July 2021 ).

64. Kenya Climate Innovation Center Projects. Available online: https:/ /www.kcicgroup.org (accessed on 25 July 2021 ).

65. Sanyal, S. "Kenyans Are Developing Solutions for Their Own Country": Interview with Edward Mungai. Beam 2018, 6.

66. Marshall, M.; Ockwell, D.; Byrne, R. Sustainable energy for all or sustainable energy for men? Gender and the construction of identity within climate technology entrepreneurship in Kenya. Prog. Dev. Stud. 2017, 17, 148-172.

67. Environmental Management and Co-ordination Act, 1999. Revised edition, 2012. Available online: http://extwprlegs1.fao.org/ docs/pdf/ken41653.pdf (accessed on 25 July 2021).

68. Environmental Management and Co-ordination Act, 1999. Available online: http://www.nema.go.ke/index.php?option=com content\&view=article\&id=24\&Itemid=163 (accessed on 25 July 2021).

69. Constitution of Kenya. 2010. Available online: http:/ / extwprlegs1.fao.org/docs/pdf/ken127322.pdf (accessed on 25 July 2021).

70. The Climate Change Act. 2016. Available online: http://kenyalaw.org/kl/fileadmin/pdfdownloads/Acts/ClimateChangeActNo1 1of2016.pdf (accessed on 25 July 2021).

71. Wambua, C. The Kenya Climate Change Act 2016: Emerging Lessons from a Pioneer Law. Carbon Clim. Law Rev. 2019, 13, 257-269. [CrossRef]

72. Mallowah, S.; Oyier, C. The Environment and Climate Change Law Review: Kenya. The Law Reviews. 2021. Available online: https:/ / thelawreviews.co.uk/title/the-environment-and-climate-change-law-review/kenya (accessed on 25 July 2021).

73. Government of Kenya, The Sustainable Waste Management Bill. 2019. Available online: http://www.environment.go.ke/wpcontent/uploads/2019/05/04-05-2019-NATIONAL-WASTE-MANAGEMENT-BILL-2019.pdf (accessed on 25 July 2021).

74. Ministry of Environment and Forestry, National Climate Change Action Plan 2018-2022, Volume 1. Available online: http:/ /www. environment.go.ke/wp-content/uploads/2020/03/NCCAP_2018-2022_ExecutiveSummary-Compressed-1.pdf (accessed on 25 July 2021).

75. Ministry of Environment and Forestry. National Sustainable Waste Management Policy. Discussion Draft. September 2018. Available online: http:/ / www.environment.go.ke/wp-content/uploads/2019/01/Waste-Policy-DISCUSSION-DRAFT-10-2-1 8.pdf (accessed on 25 July 2021).

76. Ministry of Environment and Natural Resources. Kenya's Intended Nationally Determined Contribution (INDC). 23 July 2015. Available online: https://www4.unfccc.int/sites/ndcstaging/PublishedDocuments/Kenya\%20First/Kenya_NDC_20150723.pdf (accessed on 25 July 2021).

77. National Environment Management Authority, Education for Sustainable Development (ESD): Kenya Country Report, 2005-2012. Available online: http:/ / www.nema.go.ke/images/Docs/Guidelines/the\%20status\%20of\%20esd $\% 20 \mathrm{in} \% 20 \mathrm{kenya} \% 20 \mathrm{draft} \%$ 201\%20better\%20version.pdf (accessed on 25 July 2021).

78. Kenya Organization for Environmental Education. Available online: https:/ / koeeorg.wordpress.com (accessed on 25 July 2021 ).

79. Petry, R.A.; Benko, L.M.; Koganezawa, T.; Ichinose, T.; Otieno, M.; Wade, R. Regional centres of expertise as mobilising mechanisms for education for sustainable development. In The Challenge of Sustainability: Linking Politics, Education and Learning; Atkinson, H., Wade, R., Eds.; Policy Press: Bristol, UK, 2014; pp. 181-204.

80. Kenya Institute of Curriculum Development. National Curriculum Policy. December 2018. Available online: https://kicd.ac.ke/ curriculum-reform/national-curriculum-policy/ (accessed on 25 July 2021).

81. Obonyo, P.M. The Role of NGOs in Financing Public Primary Education in Kenya: A Case of Budalangi Division, Busia District, Kenya. Master's Thesis, Kenyatta University, Nairobi, Kenya, 2011.

82. Mekaela Academies, Our Schools. Available online: https:/ / mekaela.co.ke (accessed on 25 July 2021).

83. Mekaela Academies, Mekaela Weber School. Available online: https://mekaela.co.ke/index.php/home/our-schools/mekaelaweber-school (accessed on 25 July 2021).

84. Watoto e.V. Just to Say Thank You. Available online: https:// watoto.de/en/just-to-say-thank-you/ (accessed on 25 July 2021). 
85. Faith Nyamai, Forget Cash from State, Knut Tells Private Schools. Daily Nation, 12 June 2020. Available online: https: //www.nation.co.ke/kenya/news/education/forget-cash-state-knut-tells-private-schools-654810 (accessed on 25 July 2021 ).

86. Watoto. Micro Medical Scheme. Available online: https://watoto.de/en/support/medical-scheme/ (accessed on 12 June 2020 ).

87. Noble Domestic Agency. Available online: https://nobleda.com (accessed on 25 July 2021).

88. Watoto e.V. Mekaela Academies Among the Top Ten Again. Available online: https://watoto.de/en/mekaela-academies-onceagain-among-the-top-10-primary-schools / (accessed on 25 July 2021).

89. Nation Team, Kwale Schools Shine in Coast as New Entrants Shake Up Old Order. Daily Nation, 19 November 2019. Available online: https: / / www.nation.co.ke/news/education/2019-KCPE--Kwale-schools-shine-in-Coast-/2643604-5355290-147kqp3 z/index.html (accessed on 25 July 2021).

90. Kenya Cradle, Lulu High School. Available online: https:/ / kenyacradle.com/lulu-high-school/ (accessed on 25 July 2021).

91. Hahn, K. Reform mit Augenmaß. Ausgewählte Schriften eines Politikers und Pädagogen; Knoll, M., Ed.; Klett-Cotta: Stuttgart, Germany, 1998.

92. Veevers, N.; Allison, P. Kurt Hahn: Inspirational, Visionary, Outdoor and Experiential Educator; Sense: Rotterdam, The Netherlands, 2011.

93. An Automatic Flashing System. Mekaela Times v. 12 (2018/2019): 6. Available online: https://watoto.de/wp-content/uploads / 2019/02/MT2018V2web.pdf (accessed on 25 July 2021).

94. Girls' Hope e.V. So Helfen Sie. Available online: http:/ / www.girlshope.de/ (accessed on 25 July 2021).

95. Girls' Hope e.V. Finanzen. Available online: http:/ / www.girlshope.de/kenia.php (accessed on 25 July 2021).

96. Girls' Hope e.V. Finanzen: Jahresbericht. 2013. Available online: http://www.girlshope.de/Dokumente/Jahresbericht_GH_2013 .pdf (accessed on 25 July 2021).

97. SODIS, SODIS Method. Available online: https://www.sodis.ch/methode/index_EN.html (accessed on 25 July 2021 ).

98. EcoSan Waterless Toilet System. Available online: http://www.ecosan.co.za (accessed on 25 July 2021).

99. Wangari Maathai. Wikipedia. Available online: https://en.wikipedia.org/wiki/Wangari_Maathai (accessed on 25 July 2021).

100. Solnit, R. A Paradise Built in Hell: The Extraordinary Communities that Arise in Disaster; Penguin: New York, NY, USA, 2009. 